\title{
EDITORIAL
}

\section{CONSTIPATION AND SERUM TOTAL PROSTATE SPECIFIC ANTIGEN LEVEL IN MEN}

Prostate specific antigen (PSA) is the most commonly used tumor indicator for the detection of prostate cancer despite some of its deficiencies.

The measurement of PSA has many deficiencies in the detection of prostate cancer especially early prostate cancer. Although serum PSA levels are more than $4 \mathrm{ng} /$ $\mathrm{ml}$ in one-third of BPH patients, Serum PSA level are lower than $4 \mathrm{ng} / \mathrm{ml}$ in one-third of early prostate cancer [1-2].

Some factors can increase serum PSA level. Constipation might be one of the factors because of its mechanical and physiological effects on the prostate.

Constipation potentially affects prostatic tissue in a manner similar to urological manipulation.

Constipation is common in the elderly group of patients with a prevalence rate between 2-28\%[1-3]. According to a study serum PSA level was measured in 136 constipated male patients before and after treatment. They concluded that constipation increase serum PSA level in men. The presence of constipation must be considered in patients where PSA is examined especially in those with PSA level that are borderline high or in the range of $2-10 \mathrm{ng} / \mathrm{ml}$.
The identification and effective treatment of constipated patients might avoid unnecessary prostate biopsies. This deserves proper attention of the urologists.

Bangladesh J. Urol. 2015; 18(1): 01

\section{Isteaq Ahmed Shameem}

Member, Editorial Board, Bangladesh Journal of Urology

Conflict of Interest: None Declared.

\section{References:}

1. Stamey TA, Yang N, Hey AR, McNeel JE, Freihen FS, Redwine E. Prostate specific antigen as a Serum marker in adeno carcinoma of the prostate. Eng J. Med 1987; 317. 909-16.

2. Carter HB, Altaf ME, Partin AW. Diagnosis and staging of prostate cancer. In: Kavoss LR, Novick AL, Partin AW, Peters CA (eds). Campbell Walsh Urology, Vol. 13. Saunders - Elsevier. Philadelphia. 2007:2913-31.

3. Oesterling JE, Rice DC, Glenski WJ, Bergstralh EJ. Effect of cystoscopy, prostate biopsy and transurethral resection of prostate on serum prostate specific antigen concentration. Urology, 1993; 42; 276-82.

\section{Abbreviation:}

BPH : Benign Prostatic Hyperplasia

PSA : Prostate specific antigen 